N.A. Drizhd, orcid.org/0000-0001-7269-7626,

Zh.T. Dauletzhanova, orcid.org/0000-0001-9682-5127,

N. M. Zamaliyev, orcid.org/0000-0003-0628-2654, A. Zh. Dauletzhanov, orcid.org/0000-0002-1770-3728

\title{
INFLUENCE OF TECHNOLOGICAL PROCESS PARAMETERS ON QUALITATIVE CHARACTERISTICS OF COAL THERMOLYSIS PRODUCTS
}

Purpose. To determine and compare the qualitative and quantitative characteristics of products obtained under different coking conditions to streamline the process and consider the deeper use of recycled materials at Shubarkol Komir JSC.

Methodology. Based on the existing coking technology on the basis of the enterprise, two variants of temperature exposure to coal were tested. The first option is heating coal to $900{ }^{\circ} \mathrm{C}$, which is carried out by slow thermolysis of coal in a stream of ascending gases. The second option is high-speed heating of coal to $900{ }^{\circ} \mathrm{C}$ with further loading of the released products into the chamber for additional pyrolysis at $800^{\circ} \mathrm{C}$, which is carried out with the development of reactions involving oxygen-containing gases from the furnace and from the outside.

Findings. At the production site as well as under laboratory conditions, the composition and quality characteristics of the products of heat treatment of long-flame coal under various temperature effects were determined. Differences in the composition of decomposition products were noted and their quantitative yield was determined.

Originality. Analytical data on coking products have been obtained and the dependences of their quantitative and physical parameters on different applications of thermolysis on the coals of the Shubarkol deposit have been established.

Practical value. The results of the work allow improving the technology of coke production by introducing an additional stage of pyrolysis, which will lead to an improvement in the consumer properties of coke, and also create conditions for the development of methods for using secondary production products.

Keywords: coal, Shubarkol, volatile substances, pyrolysis, coking, thermolysis, thermal degradation

Introduction. Coal, as a solid, is a complex dispersed system consisting of three main parts: organic matter, moisture and mineral components, which, being in interaction, determine, in general, the physicochemical properties of the system. It is actively used as a fuel for the production and conversion of energy, and with the development of the chemical industry and the demand for rare and valuable materials in other industries, the demand for coal increases [1]. Meanwhile, a significant decrease in the need for coal raw materials as an energy source is predicted in the next $30-40$ years, therefore, the rational use of rich coal deposits is the study and development of processing technologies for this source of raw materials [2].

The world chemical industry has successfully mastered technologies for the production of liquid fuels and rare metals from coal. Coal is a raw material for obtaining composite carbon-graphite materials with a high content of carbon, gaseous fuel of high calorific value, methods of plastic production have been developed [3]. The lowest-grade coal, its very fine fraction and coal dust are processed and pressed into coal briquettes, which are excellent for heating both industrial premises and private houses. In total, with the help of chemical processing of coal, more than 400 types of products are produced, which can cost tens of times more than the initial product [4].

More than $50 \%$ of coal production falls on the provision of the energy sector of the economy of the Republic of Kazakhstan as fuel, and $20 \%$ of the coal produced is exported in physical terms. At the same time, every year there is a decrease in external demand for Kazakhstani coal, therefore, the country's coal industry needs other ways of rational use of the extracted raw materials. Thus, at the beginning of 2019 the Republic of Kazakhstan hosted a forum of the country's coal miners, where the need for the development of deep coal processing was noted [5]. Thus, with all the peculiarities of the

(C) Drizhd N.A., Dauletzhanova Zh.T., Zamaliyev N. M., Dauletzhanov A. Zh., 2021 geological origin of coal reserves on the territory of Kazakhstan, the study on the qualitative characteristics of raw materials is a fundamental step in the development of the country's coal processing industry.

Shubarkol coal, suitable for both power engineering and metallurgy, has a high calorific value and low ash content with a lower sulfur and moisture content; it can be used in the technology for producing alumina [6].

A significant advantage of coal as a raw material for the production of high-quality coke is the following:

- low ash content $\left(A^{d}\right)$, which, according to the research results, averages $2.0 \%$;

- low content of total sulfur $\left(S^{d}\right)$ on average $0.21 \%$ and very low content of phosphorus $\left(P^{d}\right)$, equal to $0.005 \%$;

- high yield of volatile substances $\left(V_{d a f}=43-45 \%\right)$ with low ash content $\left(A^{d}=3-5 \%\right)$, which makes it possible to obtain the country's own gas in the required amount as a heat carrier for the process;

- the content of fixed carbon $\left(C_{f i x}\right)$ is high enough for grade $D$ coal and is $55.3 \%$;

- the gross calorific value $\left(Q^{d a f} \mathrm{~s}\right)$ of coal is $7400 \mathrm{kcal} / \mathrm{kg}$ $(30.98 \mathrm{MJ} / \mathrm{kg})$, the net $($ Qri $)-6460 \mathrm{kcal} / \mathrm{kg}(27.05 \mathrm{MJ} / \mathrm{kg})$, which indicates the possibility of using coal as an energy fuel [7];

- hygroscopic moisture (Whi) in coal is $5.0 \%$, and also when viewed under a microscope, vitrinite grains of regular shape have clear even boundaries. This indicates the absence of signs of oxidation;

- high density (real and apparent), low porosity, equal to $15.8 \%$ and a small pore volume $\left(0.138 \mathrm{~g} / \mathrm{cm}^{3}\right)$;

The structural strength of coal (coal free from cracks) of the $6-3 \mathrm{~mm}$ class is relatively low and averages $62.8 \%$.

To ensure more efficient use of coal in the process of coking in vertical furnaces with internal heating at Shubarkol Komir JSC, it is necessary to study the dynamics of changes in the composition and quality indicators of heat treatment products of long-flame coal, depending on the level of temperature exposure. It is known that during the heat treatment of coal, structural transformations occur in coal and, as a re- 
sult, changes in the composition and volumes of steam-gas products, consisting of its own gas, chemical products (including tar) and pyrogenetic moisture. Thus, the study on the peculiarities of pyrolysis variations, under conditions approaching the operating conditions of furnaces and their possible options, the determination of all thermolysis products will help to assess the ways of rationalizing coke production.

Experimental part. Property studies on the products after coal thermal decomposition. The experimental technique was as follows: The experiments were carried out in a single-section coking oven (clause 4.2 of GOST) [8]. The method is based on heating the test coal to $900{ }^{\circ} \mathrm{C}$ (without air access) in a coking oven to obtain primary chemical products, which are then sent for subsequent pyrolysis into a special chamber heated to $800^{\circ} \mathrm{C}$, where they are kept in within 20 minutes.

During the experiments, it was taken into account that in the process of coking in vertical furnaces with internal heating at Sary-Arka Koks LLC, "raw" coal D is heated from low temperatures to $750-800^{\circ} \mathrm{C}$ (in some places of the furnace up to $900{ }^{\circ} \mathrm{C}$ ). Therefore, in contrast to the conditions of GOST 18635-73, experiments were carried out when heating coal in a coking oven from 500 to $900{ }^{\circ} \mathrm{C}$ every $100{ }^{\circ} \mathrm{C}$ in two versions:

I - capturing the formed primary chemical products without sending them to the additional pyrolysis chamber;

II - capturing the formed chemical products and directing them to the additional pyrolysis chamber heated to $800{ }^{\circ} \mathrm{C}$.

In both versions, the yield of chemical products (gaseous, liquid and solid), the composition of the emitted gas, its density and the heat of combustion were determined.

The options for the temperature impact on coal were selected from the following considerations. Heating without additional pyrolysis (basic version) can correspond to the conditions of slow heating of the furnace coal in the flow of rising gases. Heating with pyrolysis corresponds to the conditions of high-speed heating with the development of reactions with the participation of oxygen-containing gases from the furnace and from the outside (air suction). Both options are possible under the actual operating conditions of the furnace [9]. The results of the experiments are shown in Tables 1 and 2.

Analysis of the yield and composition of gaseous products during heating of Shubarkol coal within the range from 500 to $900{ }^{\circ} \mathrm{C}$ was carried out on the basis of the results obtained (Tables 1 and 2).

The yield of chemical products was determined in accordance with GOST 18635-73 "Method for determining the yield of chemical coking products" at the installation, the diagram of which is shown in Fig. 1.

Property studies on the coke after different temperatures of additional calcination. As a rule, the use of carbonaceous materials that play the role of carbonaceous reductants or fuel is associated with their entry into the zone of high temperatures of the technological unit (blast furnaces, electrothermal, sintering, carbide, phosphoric, and so on).

This experiment will make it possible to evaluate the possibility of improving the properties of coke by introducing additional pyrolysis into the coking process. Including observation of the change in the quality of coke during secondary heating will allow considering the effectiveness of application in various high-temperature industries.

Experiments on heating coke of three classes $(25-40,10-$ 25, 0-10 mm) were carried out in two stages: 1) heating (calcination) to $700-900{ }^{\circ} \mathrm{C}$ and 2) high-temperature heating to $1000-1700{ }^{\circ} \mathrm{C}$.

Results and discussion. When heated, about $42-45 \%$ of volatile products are released from long-flame coal, and the bulk of them are intense - in the range of $400-600{ }^{\circ} \mathrm{C}$. At low temperatures, only unstable side groups of atoms are split off from the macromolecule of the coal substance, mainly in the form of $\mathrm{CO}_{2}, \mathrm{H}_{2} \mathrm{O}$ and heavy hydrocarbons (resin vapors), the process ends with the formation of semicoke. With a further increase in temperature, the reactions of aromatization and polycyclization are intensified (with the elimination of gaseous products, mainly $\mathrm{H}_{2}$, and in a smaller amount $-\mathrm{CH}_{4}, \mathrm{CO}$, $\mathrm{N}_{2}$ ), the formation of higher molecular weight polycyclic systems of a network structure occurs. This process requires sig-

The yield and composition of chemical products when heated $\left(500-900{ }^{\circ} \mathrm{C}\right)$ Shubarkol coal without additional pyrolysis

\begin{tabular}{|c|c|c|c|c|c|}
\hline \multirow{2}{*}{ Indicators } & \multicolumn{5}{|c|}{ Temperature, ${ }^{\circ} \mathrm{C}$} \\
\hline & 500 & 600 & 700 & 800 & 900 \\
\hline $\begin{array}{l}\text { Chemical product yield } \\
\text { on (dry weight), \%: mass } \\
\text { - pyrogenetic moisture } \\
\text { - resin } \\
\text { - benzene } \\
\text { - ammonia } \\
\text { - gas } \\
\text { - semi-coke (coke) }\end{array}$ & $\begin{array}{c}- \\
15.93 \\
1.40 \\
0.14 \\
5.84 \\
76.69\end{array}$ & $\begin{array}{c}0.90 \\
18.16 \\
1.66 \\
0.17 \\
10.23 \\
68.88\end{array}$ & $\begin{array}{c}4.18 \\
15.23 \\
1.71 \\
0.28 \\
13.37 \\
65.23\end{array}$ & $\begin{array}{c}9.54 \\
10.53 \\
1.30 \\
0.40 \\
15.01 \\
63.22\end{array}$ & $\begin{array}{c}8.60 \\
10.03 \\
1.00 \\
0.46 \\
16.14 \\
62.31\end{array}$ \\
\hline $\begin{array}{l}\text { Gas composition, } \% \text { by volume: } \\
\mathrm{H}_{2} \mathrm{~S} \\
\mathrm{CO}_{2} \\
\mathrm{C}_{m} \mathrm{H}_{n} \\
\mathrm{O}_{2} \\
\mathrm{CO} \\
\mathrm{H}_{2} \\
\mathrm{CH}_{4} \\
\mathrm{~N}_{2}\end{array}$ & $\begin{array}{c}1.56 \\
26.87 \\
0.0 \\
10.67 \\
8.41 \\
0.0 \\
7.77 \\
44.78\end{array}$ & $\begin{array}{c}1.16 \\
18.65 \\
0 \\
7.56 \\
14.91 \\
0.0 \\
24.44 \\
33.31\end{array}$ & $\begin{array}{c}1.52 \\
14.15 \\
0 \\
5.02 \\
18.27 \\
10.25 \\
28.47 \\
22.32\end{array}$ & $\begin{array}{c}0.86 \\
10.98 \\
0.49 \\
3.82 \\
20.33 \\
17.77 \\
28.17 \\
17.59\end{array}$ & $\begin{array}{c}1.41 \\
8.99 \\
0.30 \\
3.20 \\
20.02 \\
21.20 \\
28.29 \\
16.59\end{array}$ \\
\hline Sum $\mathrm{H}_{2}, \mathrm{CO}, \mathrm{CH}_{4}$ & 16.18 & 39.35 & 56.99 & 66.27 & 69.51 \\
\hline Gas density, $\mathrm{kg} / \mathrm{m}^{3}$ & 1.4286 & 1.2730 & 1.0959 & 0.9389 & 0.9253 \\
\hline Gas combustion heat (lowest), $\mathrm{MJ} / \mathrm{m}^{3}, \mathrm{kcal} / \mathrm{m}^{3}$ & $\frac{3.82}{913}$ & $\frac{10.63}{2540}$ & $\frac{13.61}{3251}$ & $\frac{14.87}{3552}$ & $\frac{15.13}{3614}$ \\
\hline $\begin{array}{l}\text { Gas output, } \mathrm{m}^{3} / \mathrm{t} \text { dry coal: } \\
\text { - actual } \\
\text { - reduced to } 16.76 \mathrm{MJ}(4000 \mathrm{kcal})\end{array}$ & $\begin{array}{l}53 \\
13\end{array}$ & $\begin{array}{c}103 \\
65\end{array}$ & $\begin{array}{l}154 \\
125\end{array}$ & $\begin{array}{l}193 \\
176\end{array}$ & $\begin{array}{l}230 \\
208\end{array}$ \\
\hline
\end{tabular}


Table 2

Yield and composition of chemical products when heated $\left(500-900{ }^{\circ} \mathrm{C}\right)$ of Shubarkol coal with additional pyrolysis at $800{ }^{\circ} \mathrm{C}$

\begin{tabular}{|c|c|c|c|c|c|}
\hline \multirow{2}{*}{ Indicators } & \multicolumn{5}{|c|}{ Temperature, ${ }^{\circ} \mathrm{C}$} \\
\hline & 500 & 600 & 700 & 800 & 900 \\
\hline $\begin{array}{l}\text { Chemical product yield } \\
\text { on (dry weight), \%: } \\
\text { - pyrogenetic moisture } \\
\text { - resin } \\
\text { - benzene } \\
\text { - ammonia } \\
\text { - gas } \\
\text { - semi-coke (coke) }\end{array}$ & $\begin{array}{c}6.74 \\
6.84 \\
1.04 \\
0.14 \\
10.84 \\
74.40\end{array}$ & $\begin{array}{c}5.10 \\
6.25 \\
1.04 \\
0.20 \\
17.90 \\
69.51\end{array}$ & $\begin{array}{c}7.30 \\
3.65 \\
1.08 \\
0.42 \\
21.87 \\
65.68\end{array}$ & $\begin{array}{c}8.36 \\
2.28 \\
0.86 \\
0.52 \\
24.10 \\
63.88\end{array}$ & $\begin{array}{c}7.03 \\
2.47 \\
1.04 \\
0.45 \\
27.27 \\
61.74\end{array}$ \\
\hline $\begin{array}{l}\text { Gas composition, \%: } \\
\mathrm{H}_{2} \mathrm{~S} \\
\mathrm{CO}_{2} \\
\mathrm{C}_{m} \mathrm{H}_{n} \\
\mathrm{O}_{2} \\
\mathrm{CO} \\
\mathrm{H}_{2} \\
\mathrm{CH}_{4} \\
\mathrm{~N}_{2}\end{array}$ & $\begin{array}{c}1.09 \\
13.77 \\
10.46 \\
0.50 \\
17.66 \\
12.73 \\
39.40 \\
4.39\end{array}$ & $\begin{array}{c}0.82 \\
12.85 \\
5.79 \\
0.50 \\
20.63 \\
15.23 \\
38.10 \\
6.08\end{array}$ & $\begin{array}{c}0.52 \\
12.84 \\
3.48 \\
0.50 \\
19.16 \\
26.08 \\
32.10 \\
5.32\end{array}$ & $\begin{array}{c}0.47 \\
11.92 \\
3.23 \\
0.50 \\
19.81 \\
31.51 \\
28.09 \\
4.47\end{array}$ & $\begin{array}{c}0.38 \\
9.35 \\
2.01 \\
0.50 \\
21.31 \\
33.20 \\
25.35 \\
7.90\end{array}$ \\
\hline Sum $\mathrm{H}_{2}, \mathrm{CO}, \mathrm{CH}_{4}$ & 69.79 & 73.96 & 77.34 & 79.41 & 79.86 \\
\hline Gas density, $\mathrm{kg} / \mathrm{m}^{3}$ & 1.0215 & 0.9811 & 0.8804 & 0.8314 & 0.8044 \\
\hline Gas combustion heat (lowest), $\mathrm{MJ} / \mathrm{m}^{3}, \mathrm{kcal} / \mathrm{m}^{3}$ & $\frac{24.00}{5733}$ & $\frac{21.37}{5105}$ & $\frac{18.83}{4497}$ & $\frac{17.90}{4276}$ & $\frac{16.56}{3955}$ \\
\hline $\begin{array}{l}\text { Gas output, } \mathrm{m}^{3} / \mathrm{t} \text { dry coal: } \\
\text { - actual } \\
\text { - reduced to } 16.76 \mathrm{MJ}(4000 \mathrm{kcal})\end{array}$ & $\begin{array}{l}113 \\
162\end{array}$ & $\begin{array}{l}165 \\
210\end{array}$ & $\begin{array}{l}252 \\
283\end{array}$ & $\begin{array}{l}300 \\
321\end{array}$ & $\begin{array}{l}396 \\
391\end{array}$ \\
\hline
\end{tabular}

nificant energy consumption and is being developed in the area of high temperatures $\left(800-900{ }^{\circ} \mathrm{C}\right)$. The release of light components into the vapor-gas phase occurs mainly when the thermally active $\mathrm{C}-\mathrm{C}$ bonds are broken, leading to the decomposition of coal macromolecules [ten].

Option I - without additional pyrolysis of products. When coal is heated from 500 to $900{ }^{\circ} \mathrm{C}$, the gas output (actual) increases by 4.5 times (from 53 to $230 \mathrm{~m}^{3} / \mathrm{t}$ of dry coal). At the same time, the content of $\mathrm{CO}_{2}$ (from 26.87 to $8.99 \%$ ), $\mathrm{O}_{2}$ (from 10.67 to $3.20 \%$ ) and $\mathrm{N}_{2}$ (from 44.78 to $16.59 \%$ ) sharply decrease. At the same time, the content of the following components increases: $\mathrm{H}_{2}$ - from $10.25 \%$ (at $700{ }^{\circ} \mathrm{C}$ ) to $21.20 \%\left(900{ }^{\circ} \mathrm{C}\right), \mathrm{CH}_{4}-$ from 7.77 to $28.29 \%$ and $\mathrm{CO}-$ from 8,41 to $20.02 \%$. In general, when heated from 500 to $900{ }^{\circ} \mathrm{C}$, the content of combustible components $\left(\mathrm{H}_{2}+\mathrm{CO}+\right.$ $\mathrm{CH}_{4}$ ) increases by 4.3 times (from 16.18 to $69.51 \%$ ). At the same time, the combustion heat of gas increases by 4 times (from 913 to $3614 \mathrm{kcal} / \mathrm{m}^{3}$ ) and its density decreases (from 1.43 to $0.92 \mathrm{~kg} / \mathrm{m}^{3}$ ).

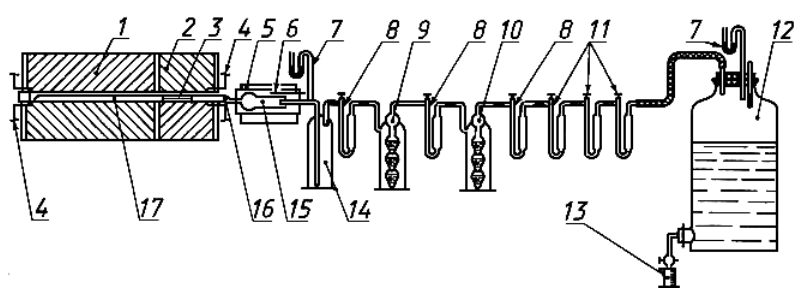

Fig. 1. Diagram of the installation for determining the yield of chemical coking products in accordance with GOST 18635: 1 - coking oven; 2 - tubular electric pyrolysis furnace; 3 - nozzle; 4 - thermal converters; 5 - tubular electric oven for a cotton filter with a thermostat; 6 - thermometer; 7 - water pressure gauge; 8 - calcium chloride tube; 9 - absorption flasks for $\mathrm{CO}_{2}$ and $\mathrm{H}_{2} \mathrm{~S}$; 10 - absorption flasks for unsaturated hydrocarbons; 11 - tubes with activated carbon; 12 - gas meter; 13 - measuring cylinder; 14 - absorption flask for ammonia; 15 - filter for collecting resin; 16 - quartz insert; 17 - reaction quartz tube
Option II - with additional pyrolysis of products. The gas output (actual) increases by 3.5 times and reaches a maximum value of $396 \mathrm{~m}^{3} / \mathrm{t}$ at $900{ }^{\circ} \mathrm{C}$. Less dramatically, in comparison with option $\mathrm{I}$, the $\mathrm{CO}_{2}$ content decreases (from 13.77 to $9.35 \%$ ), the $\mathrm{N}_{2}$ content increases from 4.39 to $7.90 \%$. The content of $\mathrm{O}_{2}$ according to the conditions of the experiment (according to GOST 18635-73) was taken constant (0.5\%). The content of low-molecular combustible components $\left(\mathrm{H}_{2}+\right.$ $+\mathrm{CO}+\mathrm{CH}_{4}$ ) continues to grow - from 69.79 to $79.86 \%$; however, the total heat of combustion decreases (from 5733 to $3955 \mathrm{kcal} / \mathrm{m}^{3}$ ), apparently due to a 1.55 -fold decrease content of $\mathrm{CH}_{4}$ (from 39.40 to $25.35 \%$ ).

Studies have shown that when Shubarkol coal is heated to $900{ }^{\circ} \mathrm{C}$ with additional pyrolysis (at $800{ }^{\circ} \mathrm{C}$ ), the hydrogen concentration in the gas increases and is about $33 \%$, and the sum of $\mathrm{H}_{2}, \mathrm{CO}, \mathrm{CH}_{4}$ gases reaches $80 \%$ (Table 2). Any dilution of gaseous products with low-reactive components, for example, in variant I or in the low-temperature region (500$600{ }^{\circ} \mathrm{C}$ ) in variant II, reduces their reduction capabilities: the $\mathrm{H}_{2}$ content is about $12-21 \%$, the $\mathrm{H}_{2}+\mathrm{CO}+\mathrm{CH}_{4}$ share decreases to $66-74 \%$ (Tables 1 and 2).

Figs. 2 and 3 show the dynamics of changes in the yield of chemical products from coal, respectively, without implementing additional pyrolysis and after additional pyrolysis.

Fig. 4 shows the dynamics of the formation of the sum of gases $\mathrm{H}_{2}, \mathrm{CO}, \mathrm{CH}_{4}$ from coal without additional pyrolysis (a) and with additional pyrolysis (b) of coal.

Fig. 5 shows the dynamics of changes in gas density during tests for options I and II.

Fig. 6 shows the dynamics of gas discharge without additional pyrolysis and after additional pyrolysis.

As for the resin for heat treatment of coal, its main amount is formed at the stage of semi-coking at a temperature of 550$600{ }^{\circ} \mathrm{C}$. Under conditions when volatile products leave the reaction zone without being exposed to higher temperatures as in option II, the resulting resin hardly changes its primary character.

The quality of the resulting resin is shown in Table 3. 


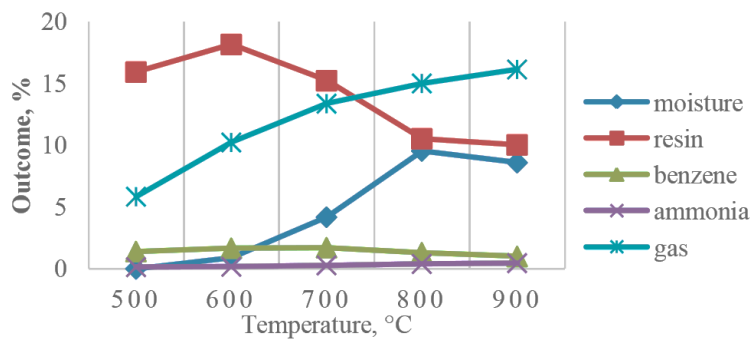

Fig. 2. Yield of chemical products with option I (without additional pyrolysis)

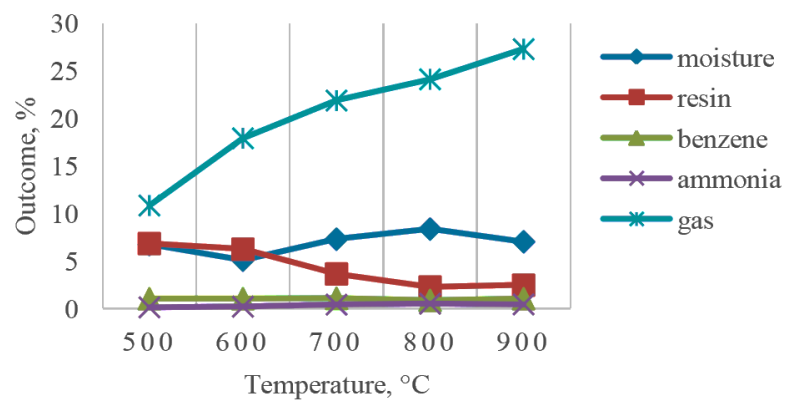

Fig. 3. Yield of chemical products under option II (after additional pyrolysis)

Qualitative characteristics of coke when heated within 700$900^{\circ} \mathrm{C}$. High viscosity and heat of combustion $(9150 \mathrm{kcal} / \mathrm{kg})$ should be noted among the important performance indicators of resin quality. There is also an increased content of phenols $(22.4 \%)$. The pour point of the resin is at $+10{ }^{\circ} \mathrm{C}$.

Changes in the quality characteristics of coke calcined to $900{ }^{\circ} \mathrm{C}$ are shown in Tables 4 and 5 .

For 25-40 $\mathrm{mm}$ coke, with an increase in the heating temperature from 700 to $900{ }^{\circ} \mathrm{C}$ (Table 4), the yield of the original 25-40 mm class decreases from 92.5 to $84.6 \%$, although the formation of $0-10 \mathrm{~mm}$ fines is minimal (1.9-2.3\%).

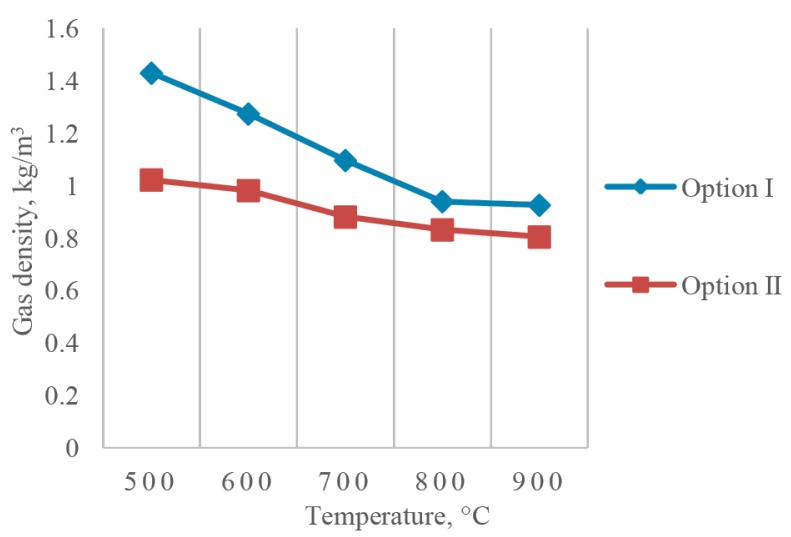

Fig. 5. Gas density for option I (without additional pyrolysis) and option II (after additional pyrolysis)

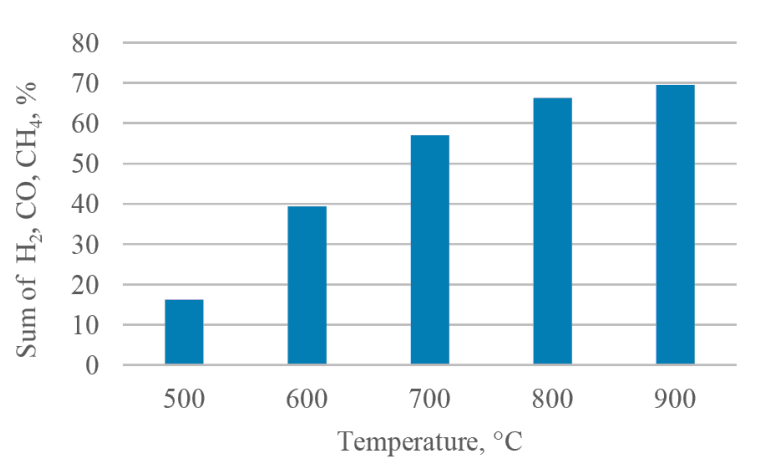

$a$

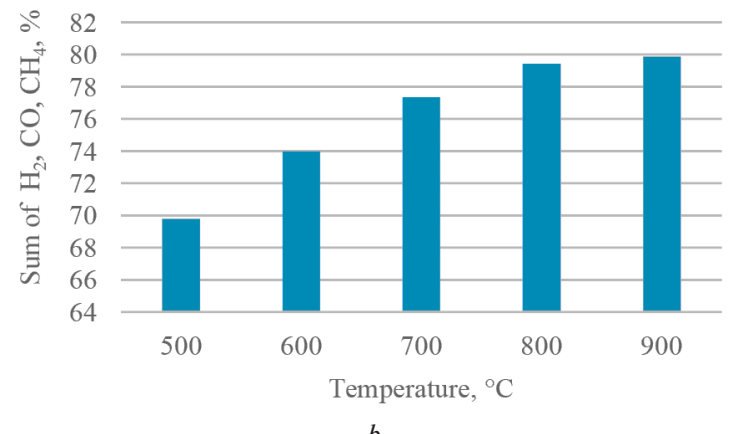

Fig. 4. The sum of $\mathrm{H}_{2}, \mathrm{CO}, \mathrm{CH}_{4}$ (the difference in outputs with and without additional pyrolysis):

$a$ - without additional pyrolysis; $b$ - after additional pyrolysis

The mechanical strength of the calcined coke is quite high and in terms of the yield of $25-40 \mathrm{~mm}$ class is $67.7-60.6 \%$ with the formation of fines $(0-10 \mathrm{~mm})$ up to $4.3-5.5 \%$.

For the $10-25 \mathrm{~mm}$ class, calcination to $900{ }^{\circ} \mathrm{C}$ did not significantly affect the decrease in the yield of the main class - from 98.6 to $97.3 \%$ and the formation of fines -

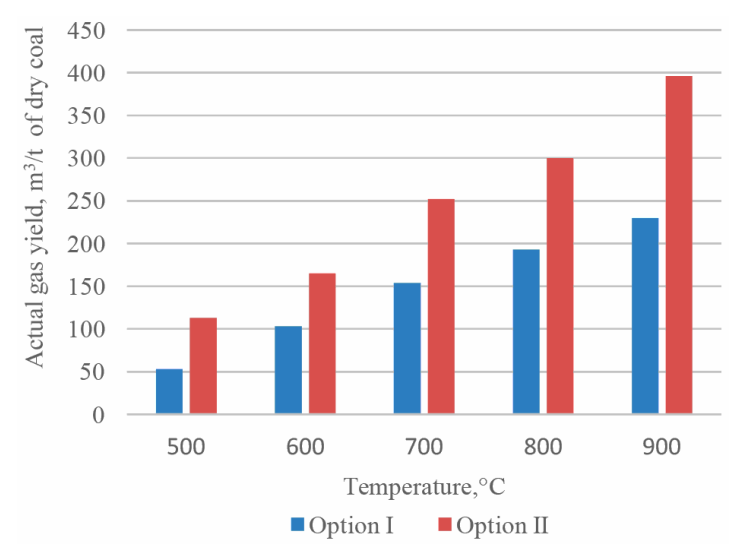

Fig. 6. Gas make for option I (without additional pyrolysis) and option II (after additional pyrolysis)

Table 3

Characteristics of pitch from coal grade D

\begin{tabular}{|c|c|c|c|c|c|c|c|c|c|c|c|c|c|c|}
\hline \multirow{2}{*}{ 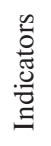 } & \multirow{2}{*}{ 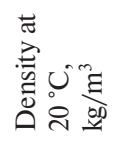 } & \multirow{2}{*}{ 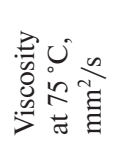 } & \multirow{2}{*}{ 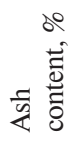 } & \multirow{2}{*}{ 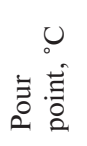 } & \multirow{2}{*}{ 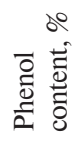 } & \multicolumn{4}{|c|}{ Elemental composition, $\%$} & \multicolumn{4}{|c|}{$\begin{array}{l}\text { Fractional composition, } \\
\quad \% \text { (vol) up to, }{ }^{\circ} \mathrm{C}\end{array}$} & \multirow{2}{*}{$\begin{array}{c}\text { Calorific } \\
\text { value, } \\
\text { Qdo, } \\
(\mathrm{kcal} / \mathrm{kg})\end{array}$} \\
\hline & & & & & & $\mathrm{C}$ & $\mathrm{H}$ & $\mathrm{O}+\mathrm{N}$ & $\mathrm{S}$ & 200 & 240 & 280 & 320 & \\
\hline I & 1.024 & 9.0 & 0.11 & +10 & 22.4 & 82.8 & 8.8 & 7.8 & 0.6 & 11.0 & 27.5 & 41.0 & 71.5 & 9150 \\
\hline II & 1.026 & 10.0 & 0.11 & +10 & 21.6 & 83.3 & 8.5 & 7.5 & 0.4 & 10.0 & 29.5 & 43.0 & 74.0 & 9230 \\
\hline
\end{tabular}


Influence of the coke calcination temperature on the change in its size and strength

\begin{tabular}{|c|c|c|c|c|c|c|c|c|c|}
\hline \multirow{3}{*}{ Class, mm } & \multirow{3}{*}{ Calcination, ${ }^{\circ} \mathrm{C}$} & \multicolumn{4}{|c|}{ After calcination } & \multicolumn{4}{|c|}{ After dropping } \\
\hline & & \multicolumn{3}{|c|}{$\begin{array}{l}\text { Granulometric composition }(\%) \\
\text { by classes, mm }\end{array}$} & \multirow{2}{*}{$\begin{array}{c}\text { Average } \\
\text { lump size, } \\
\mathrm{mm} \\
-\end{array}$} & \multicolumn{3}{|c|}{$\begin{array}{l}\text { Granulometric composition }(\%) \\
\text { by classes, mm }\end{array}$} & \multirow{2}{*}{$\begin{array}{c}\text { Average } \\
\text { lump size, } \\
\text { mm } \\
-\end{array}$} \\
\hline & & $25-40$ & $10-25$ & $0-10$ & & $25-40$ & $10-25$ & $0-10$ & \\
\hline \multirow[t]{3}{*}{$25-40$} & 700 & 92.5 & 5.3 & 2.2 & 31.1 & 67.7 & 27.5 & 4.8 & 27.1 \\
\hline & 800 & 88.4 & 9.7 & 1.9 & 30.5 & 60.9 & 33.6 & 5.5 & 25.9 \\
\hline & 900 & 84.6 & 13.1 & 2.3 & 29.9 & 60.6 & 35.1 & 4.3 & 26.1 \\
\hline \multirow[t]{3}{*}{$10-25$} & 700 & - & 98.6 & 1.4 & 17.3 & - & 96.6 & 3.4 & 17.1 \\
\hline & 800 & - & 97.3 & 2.7 & 17.2 & - & 96.4 & 3.6 & 17.1 \\
\hline & 900 & - & 97.3 & 2.7 & 17.2 & - & 95.8 & 4.2 & 17.0 \\
\hline
\end{tabular}

from 1.4 to $2.7 \%$. The mechanical strength of the coke after calcination remained quite high and ranged from 96.6 to $95.8 \%$ with minimal formation of fines $(0-10 \mathrm{~mm})$ from 3.4 to $4.2 \%$.

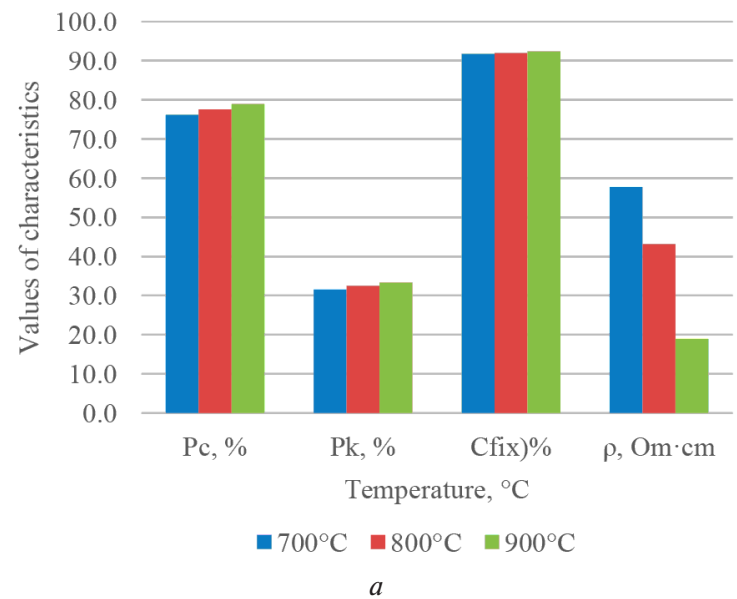

Changes in the material composition and physical and chemical properties of coke classes $(25-40,10-25$ and $0-10 \mathrm{~mm}$ ) during their calcination to $700-900{ }^{\circ} \mathrm{C}$ are shown in Table 5, and comparative diagrams are shown in Figs. 7, $a, b$.

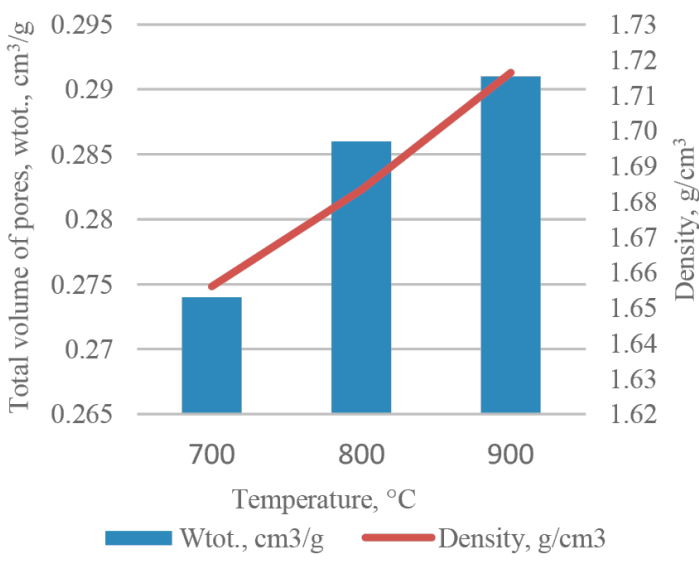

$b$

Fig. 7. Change in coke properties:

$a$ - change in density, porosity, fixed carbon and resistivity; $b$ - change in pore volume and coke density

Changes in the physical and chemical properties of coke depending on the calcination temperature

\begin{tabular}{|c|c|c|c|c|c|c|c|c|c|}
\hline \multirow{3}{*}{$\begin{array}{l}\quad \text { Indicators } \\
\text { Experimental conditions: } \\
\text { - class of coke size, mm } \\
\text { - calcination temperature, }{ }^{\circ} \mathrm{C} \\
\text { - calcination time, min }\end{array}$} & \multicolumn{9}{|c|}{ Series of experiments } \\
\hline & \multicolumn{3}{|c|}{1} & \multicolumn{3}{|c|}{2} & \multicolumn{3}{|c|}{3} \\
\hline & $\begin{array}{c}25-40 \\
700 \\
30\end{array}$ & $\begin{array}{c}25-40 \\
800 \\
30\end{array}$ & $\begin{array}{c}25-40 \\
900 \\
30\end{array}$ & $\begin{array}{c}10-25 \\
700 \\
30\end{array}$ & $\begin{array}{c}10-25 \\
800 \\
30\end{array}$ & $\begin{array}{c}10-25 \\
900 \\
30\end{array}$ & $\begin{array}{c}0-10 \\
700 \\
30\end{array}$ & $\begin{array}{c}0-10 \\
800 \\
30\end{array}$ & $\begin{array}{c}0-10 \\
900 \\
30\end{array}$ \\
\hline $\begin{array}{l}\text { Technical analysis, \%: } \\
W^{a} \\
A^{d} \\
V^{d a f} \\
S^{d}\end{array}$ & $\begin{array}{c}3.1 \\
4.2 \\
3.56 \\
0.21\end{array}$ & $\begin{array}{c}3.3 \\
4.9 \\
2.83 \\
0.24\end{array}$ & $\begin{array}{c}2.4 \\
4.9 \\
2.49 \\
0.26\end{array}$ & $\begin{array}{c}4.4 \\
5.8 \\
2.58 \\
0.25\end{array}$ & $\begin{array}{c}4.7 \\
5.8 \\
2.52 \\
0.26\end{array}$ & $\begin{array}{c}5.1 \\
6.0 \\
2.33 \\
0.28\end{array}$ & $\begin{array}{c}3.1 \\
5.2 \\
3.76 \\
0.29\end{array}$ & $\begin{array}{c}5.0 \\
5.8 \\
2.56 \\
0.26\end{array}$ & $\begin{array}{c}3.4 \\
5.8 \\
1.56 \\
0.26\end{array}$ \\
\hline Carbon content $\left(\mathrm{C}^{f i x}\right), \%$ & 92.4 & 92.4 & 92.7 & 91.8 & 91.8 & 91.8 & 91.2 & 91.8 & 92.7 \\
\hline $\begin{array}{l}\text { Specific electrical resistance in class } 6-3 \mathrm{~mm} \text {, } \\
p=0.2 \mathrm{~kg} / \mathrm{cm}^{2}, \rho, \mathrm{Ohm} \cdot \mathrm{cm}\end{array}$ & 45.3 & 41.2 & 20.6 & 39.5 & 27.4 & 15.2 & 88.5 & 60.9 & 21.2 \\
\hline $\begin{array}{l}\text { Density, } \mathrm{g} / \mathrm{cm}^{3}: \\
\text { valid, ddr } \\
\text { apparent, dda }\end{array}$ & $\begin{array}{l}1.676 \\
1.144\end{array}$ & $\begin{array}{l}1.668 \\
1.146\end{array}$ & $\begin{array}{l}1.718 \\
1.149\end{array}$ & $\begin{array}{l}1.638 \\
1.124\end{array}$ & $\begin{array}{l}1.690 \\
1.136\end{array}$ & $\begin{array}{l}1.692 \\
1.143\end{array}$ & $\begin{array}{l}1.654 \\
1.141\end{array}$ & $\begin{array}{l}1.692 \\
1.127\end{array}$ & $\begin{array}{l}1.739 \\
1.141\end{array}$ \\
\hline Porosity, $P c \%$ & 31.7 & 31.3 & 33.1 & 31.8 & 32.8 & 32.4 & 31.0 & 33.4 & 34.4 \\
\hline Total pore volume, Wtot., $\mathrm{cm}^{3} / \mathrm{g}$ & 0.277 & 0.273 & 0.288 & 0.273 & 0.289 & 0.284 & 0.272 & 0.296 & 0.301 \\
\hline Structural strength, Ps, $\%$ & 77.4 & 78.1 & 80.4 & 75.8 & 78.7 & 80.1 & 75.4 & 75.8 & 76.5 \\
\hline
\end{tabular}


After heat treatment of coke classes at $700-900{ }^{\circ} \mathrm{C}$ the following changes in their properties took place. Common signs of the influence of the calcination temperature on the quality of all classes of coke are:

- increase in ash content (by $0.2-0.7 \%$ abs. depending on the class of coke);

- a sharp decrease in the yield of volatile substances, especially in the class $0-10 \mathrm{~mm}$ (from 3.76 to $1.56 \%$ );

- almost unchanged content of fixed carbon $\left(\mathrm{C}^{f i x}\right)$ for classes $25-40$ and $10-25 \mathrm{~mm}$ and a slight increase in $\mathrm{C}^{\text {fix }}$ for class $0-10 \mathrm{~mm}$ (from 91.2 to $92.7 \%$ );

- the development of a porous structure with an increase in the total porosity for all classes - on average from 31.0-31.8 to $32.4-34.4 \%$ and the total pore volume - from $0.272-0.277$ to $0.284-0.301 \mathrm{~cm}^{3} / \mathrm{g}$;

- a sharp decrease in electrical resistivity (ESR) for the $25-40 \mathrm{~mm}$ class - by 2.2 times, for the $10-25 \mathrm{~mm}$ class - by 2.6 times and for the $0-10 \mathrm{~mm}$ class - by 4.2 times. However, its level after calcination of all classes $(15-88 \mathrm{Ohm} \cdot \mathrm{cm}) \mathrm{sig}-$ nificantly exceeds the USE of metallurgical coke (2.5$4.0 \mathrm{Ohm} \cdot \mathrm{cm})$;

- increase in structural strength, especially in classes $25-40$ and $10-25 \mathrm{~mm}$ from $75.8-77.4$ to $80.1-80.4 \%$, and less significantly - for fines of class $0-10 \mathrm{~mm}$ - from 75.4 to $76.5 \%$.

High-temperature treatment of coke in the range of 1000$1700{ }^{\circ} \mathrm{C}$. Changes in the physicochemical properties of coke of the $10-25 \mathrm{~mm}$ class were studied when heated to $1000-$ $1700{ }^{\circ} \mathrm{C}$ (Table 5).

The tendencies of changes in the properties of coke during high-temperature calcination are as follows:

- in comparison with the original class, during calcination, its ash content increases to $4.9-5.2 \%$;

- the yield of volatile substances changes particularly sharply: at $1000{ }^{\circ} \mathrm{C}$ the sleep is $2.0 \%$ (for the initial one $4.4 \%$ ), and at $1700{ }^{\circ} \mathrm{C}$ it decreases to $0.8 \%$;

- the content of the total sulfur of coke in the conducted experiments increases from 0.22 to $0.26 \%$, although there is information on the calcination of metallurgical coke, indicating a decrease in sulfur when heated to similar temperatures;
- the content of fixed carbon increases from 92.9 to $94.1 \%$. The carbon content per organic matter $\left(\mathrm{C}^{\text {daf }}\right)$ reaches its maximum value (98.30 and $98.65 \%$ ) for cokes calcined at 1400 and $1700{ }^{\circ} \mathrm{C}$. In the elemental composition of cokes calcined at $1700{ }^{\circ} \mathrm{C}$, the content of hydrogen and oxygen sharply decreases - to 0.24 and $0.27 \%$, respectively (for the initial one, 1.28 and $3.33 \%$ );

- by an order of magnitude (in comparison with the initial coke), the specific electrical resistance decreases from 66.6 to $3.0 \mathrm{Ohm} \cdot \mathrm{cm}$, which at $1400-1700{ }^{\circ} \mathrm{C}$ approaches the level of ECS of metallurgical coke $(2.5-4.0 \mathrm{Ohm} \cdot \mathrm{cm})$;

- the reactivity at $1000{ }^{\circ} \mathrm{C}$ is at the level of that of the initial coke 15.02 against $4.78 \mathrm{~cm}^{3} / \mathrm{g} \cdot \mathrm{s}$, and at $1400-1700{ }^{\circ} \mathrm{C}$ it sharply decreases, reaching $2.24-2.75 \mathrm{~cm}^{3} / \mathrm{g} \cdot \mathrm{s}$. However, this level is rather high in comparison, for example, with blast furnace coke $\left(0.30-0.60 \mathrm{~cm}^{3} / \mathrm{g} \cdot \mathrm{s}\right)$;

- the structural strength of coke at $1700{ }^{\circ} \mathrm{C}$ decreases to $73.1 \%$ (for the original $80.9 \%$ );

- the porosity of the calcined coke increases and reaches an average value of $42.5 \%$ (for the original $27.4 \%$ ). With an increase in temperature, the values of the actual and apparent density decrease. The total pore volume during calcination increases and amounts to $0.434-0.459 \mathrm{~cm}^{3} / \mathrm{g}$.

Conclusion. Coal grade $D$ of the Shubarkol deposit by its complex of material and mineral composition, physicochemical and mechanical properties is a unique raw material for the production of a special carbonaceous product from it in thermal furnaces. The quality indicators of coal have created the practical implementation of industrial production of coke in vertical furnaces with internal heating at Shubarkol Komir JSC. A significant disadvantage of coal is its lowered values of structural and thermal strength indicators, which can cause relatively fine coke to be obtained.

In general, the research results indicate a sufficiently high reductive ability of volatile products of thermal decomposition of long-flame coal and the possibility of their significant increase by additional pyrolysis. Comparative analysis of gas composition when heating Shubarkol coal to 500-900 ${ }^{\circ} \mathrm{C}$ without additional pyrolysis and with pyrolysis of emitted

Change in the properties of coke during high-temperature heating

\begin{tabular}{|c|c|c|c|c|}
\hline Indicators & $\begin{array}{l}\text { Initial coke class } \\
10-25 \mathrm{~mm}\end{array}$ & $1000{ }^{\circ} \mathrm{C}$ & $1400^{\circ} \mathrm{C}$ & $1700^{\circ} \mathrm{C}$ \\
\hline $\begin{array}{l}\text { Technical analysis, \%: } \\
A^{d} \\
V^{d a f} \\
S^{d}\end{array}$ & $\begin{array}{l}3.0 \\
4.4 \\
0.18\end{array}$ & $\begin{array}{c}5.2 \\
2.0 \\
0.22\end{array}$ & $\begin{array}{c}4.9 \\
1.1 \\
0.25\end{array}$ & $\begin{array}{c}5.1 \\
0.8 \\
0.26\end{array}$ \\
\hline Carbon content $\left(\mathrm{C}^{f i x}\right), \%$ & 92.7 & 92.9 & 94.0 & 94.1 \\
\hline $\begin{array}{l}\text { Elemental composition (on organic matter), \%: } \\
\mathrm{C}^{d a f} \\
\mathrm{H}^{\text {daf }} \\
\mathrm{N}^{d a f} \\
\mathrm{O}^{d a f} \\
\mathrm{~S}^{d a f}\end{array}$ & $\begin{array}{l}93.48 \\
1.28 \\
1.72 \\
3.33 \\
0.19 \\
\end{array}$ & $\begin{array}{c}96.27 \\
0.52 \\
0.91 \\
2.07 \\
0.23 \\
\end{array}$ & $\begin{array}{c}98.30 \\
0.28 \\
0.77 \\
0.39 \\
0.26 \\
\end{array}$ & $\begin{array}{r}98.65 \\
0.24 \\
0.57 \\
0.27 \\
0.27 \\
\end{array}$ \\
\hline $\mathrm{CO}_{2}$ reactivity at $1000^{\circ} \mathrm{C}, \mathrm{KCO}_{2}, \mathrm{~cm}^{3} / \mathrm{g} \cdot \mathrm{s}$ & 4.78 & 5.02 & 2.24 & 2.75 \\
\hline $\begin{array}{l}\text { Specific electrical resistance in class } 6-3 \mathrm{~mm}, p=0.2 \mathrm{~kg} / \mathrm{cm}^{2} \text {, } \\
\rho, \mathrm{Ohm} \cdot \mathrm{cm}\end{array}$ & 66.6 & 7.0 & 3.4 & 3.0 \\
\hline $\begin{array}{l}\text { Density, } \mathrm{g} / \mathrm{cm}^{3} \text { : } \\
\text { valid, ddr } \\
\text { apparent, dda }\end{array}$ & $\begin{array}{l}1.579 \\
1.146\end{array}$ & $\begin{array}{l}1.687 \\
0.974\end{array}$ & $\begin{array}{l}1.631 \\
0.944\end{array}$ & $\begin{array}{l}1.616 \\
0.928\end{array}$ \\
\hline Porosity, \% & 27.4 & 42.3 & 42.1 & 42.6 \\
\hline Total pore volume, Wtot., $\mathrm{cm}^{3} / \mathrm{g}$ & 0.239 & 0.434 & 0.446 & 0.459 \\
\hline Structural strength, Ps, $\%$ & 80.9 & 77.6 & 75.5 & 73.1 \\
\hline
\end{tabular}


products suggests the influence of volatile components of coal on the thermal regime of coke ovens, the chemical and hydrocarbon composition cause different total thermal effect of the process and their role in the formation of the structure and indicators of the quality of the resulting coke, in particular: porosity, mechanical strength, electrical resistivity, destruction in $\mathrm{CO}_{2}$, and so on.

The quality of coke during secondary heating was investigated to assess the effect of additional pyrolysis, as well as its applicability in various high-temperature industries. Analysis of changes in the quality of coke classes after secondary heating to $700-900{ }^{\circ} \mathrm{C}$ shows that heat treatment generally improves their physicochemical properties, especially when used as a carbonaceous reductant, for example, for ferroalloy production and as a class 0 fuel $-10 \mathrm{~mm}$ for ore agglomeration. Exposure to high temperature coke in all cases leads to further compaction of its fine-pored structure, which is associated with the process of intramolecular rearrangement of the coke substance (its condensation and graphitation). At the same time, the coke retains high sorption capacity, pore volume, and inner surface. However, the coke obtained from coal of grade $D$, under high-temperature heating, is subject to slight graphitation and at the same time retains a relatively developed porous structure and high indicators of physical and chemical properties.

As for the coal heat treatment resin, its main amount is formed at the semicoking stage at a temperature of 550$600{ }^{\circ} \mathrm{C}$. Under conditions when volatile products leave the reaction zone without being exposed to higher temperatures, as in option II, the resulting resin practically does not change its primary character.

In this regard, it is necessary to assess the rationality of using option II, where the actual release of volatiles differs by 1.5-2 times from the main scheme, while the energy consumption for maintaining additional pyrolysis at a constant temperature of $800{ }^{\circ} \mathrm{C}$ is also significant.

When coke is heated to temperatures of $1000-1700{ }^{\circ} \mathrm{C}$, typical for metallurgical and chemical processes, the ash content Ad increases to 4.9-5.2\%, which is still an acceptable indicator for production needs [11]. Obviously, the preservation of low values of the ash content of the feedstock provides high quality coke for high-temperature production.

Thus, the data obtained as a result of comparative tests can be used for planning production operations and technologies with the disposal of coking products and other thermal effects on coal. The component composition of the resin helps to assess the feasibility of processing secondary raw materials on the basis of an already operating industrial facility. For example, the chemical composition of the resin makes it possible to develop methods for distillation and extraction of individual groups of organic compounds. Phenol can serve as a raw material for the mining industry proper in the synthesis of polymeric antipyrogenic coatings for stacks of coal and coke during open storage or transportation of coal products in bunkers and wagons.

\section{References.}

1. Qin Zhihong (2018). New advances in coal structure model. International Journal of Mining Science and Technology, 28(4), 541-559. https://doi.org/10.1016/j.ijmst.2018.06.010.

2. Akhunbaev, A. M. (2017). State and prospects of the coal industry in Kazakhstan. Mining and Metallurgical Industry, 8, 26-29.

3. Prafulla Kumar Sahoo, Kangjoo Kim, Powell, M.A., \& Equeenuddin, Sk. Md. (2016). Recovery of metals and other beneficial products from coal fly ash: a sustainable approach for fly ash management. International Journal of Coal Science \& Technology, 3(3), 267-283. https://doi.org/10.1007/s40789016-0141-2.

4. Sekhohola, L. M., \& Cowan, A. K. (2017). Biological conversion of low-grade coal discard to a humic substance-en- riched soil-like material. International Journal of Coal Science \& Technology, 4(2), 183-190. https://doi.org/10.1007/s40789017-0167-0.

5. AGMPORTAL (2019). AGMPORTAL The future of the coal industry lies in deep processing. Retrieved from https://agmpportal.kz/budushhee-ugolnoj-otrasli-za-glubokoj-pererabotkoj/.

6. Plakitkina, L. S. (2015). Analysis of the development of the coal industry in the Republic of Kazakhstan in the period from 2000-2014, and trends of perspective development. Journal "Coal", 4, 80-82.

7. Drizhd, N.A., Dauletzhanov, A.Zh., Dauletzhanova, Zh. T., \& Zamaliev, N. M. (2019). Qualitative characteristics of coal from the Shubarkol deposit and its applicability for the production of coke. Proceedings of the University, 3(76), 45-49.

8. GOST 18635-73 (2000). Coals of stone. Method for determining the yield of coking chemical. Moscow: Ministry of Ferrous Metallurgy of the USSR. Retrieved from http://docs.cntd.ru/ document/gost-18635-73.

9. Bazhin, V. Yu., Sharikov, F. Yu., Feshchenko, R. Yu., \& Sudnitsin, E. O. (2015). Impact on the structure and properties of coals during extreme heat treatment. International scientific research journal, 7(38), 13-15.

10. Kairbekov, Zh. K., \& Suimbaeva, S. M. (2017). Scheme of the transformation of the organic mass of coal in the process of hydrogenation. Chemical Journal of Kazakhstan, 3(59), 246251 .

11. Strakhov, V. M. (2019). An effective way to improve the quality of foundry and metallurgical coke. Bulletin "Ferrous metallurgy”, 2, 147-153. https://doi.org/10.32339/0135-59102019-2-147-153.

\section{Вплив параметрів технологічних процесів на якісні характеристики продуктів термолізу вугілля}

\section{М. О. Дріжд, Ж. Т. Даулетжанова, Н. М. Замалієв, А. Ж. Даулетжканов}

Карагандинський технічний університет, м. Караганда, Республіка Казахстан, e-mail: dauletzhanov@gmail.com

Мета. Визначити й порівняти якісні та кількісні характеристики продуктів, отриманих за різних рівнів використання коксування, для раціоналізації технологічного процесу й розгляду більш глибокого використання вторинної сировини в умовах АО «Шубарколь Комір».

Методика. Виходячи з існуючої технології коксування, на базі підприємства були досліджені два варіанта температурного впливу на вугілля. Перший варіант - нагрівання вугілля до $900{ }^{\circ} \mathrm{C}$, що проводить шляхом повільного термолізу вугілля в потоці висхідних газів. Другий варіант - швидкісне нагрівання вугілля до $900{ }^{\circ} \mathrm{C} з$ подальшим завантаженням продуктів, що виділяються до камери для додаткового піролізу при $800{ }^{\circ} \mathrm{C}$, який проводиться з розвитком реакцій за участі кисневмісних газів із печі та ззовні.

Результати. На виробничому майданчику та в лабораторних умовах визначені склад і якісні характеристики продуктів термічної обробки довгополуменевого вугілля при різних температурних впливах. Відзначені відмінності у складі продуктів розкладання й визначено кількісний їх вихід.

Наукова новизна. Отримані аналітичні дані по продуктам коксування та встановлені залежності їх кількісних і фізичних параметрів від різних варіантів застосування термолізу на вугіллі Шубаркольского родовища.

Практична значимість. Результати роботи дозволяють удосконалювати технологію коксового виробництва 
шляхом уведення додаткової стадії піролізу, що призведе до покращення споживчих властивостей коксу, а також створюють умови для розробки методик використання вторинних продуктів виробництва.

Ключові слова: вугілля, Шубарколь, летючі речовини, піроліз, коксування, термоліз, термічний розклад

\section{Влияние параметров технологических процессов на качественные характеристики продуктов термолиза углей}

\section{Н. А. Дрижд, Ж. Т. Даулетжанова, Н. М. Замалиев,} А. Ж. Даулетжанов

Карагандинский технический университет, г. Караганда, Республика Казахстан, e-mail: dauletzhanov@gmail.com

Цель. Определить и сравнить качественные и количественные характеристики продуктов, полученных при разных условиях коксования, для рационализации технологического процесса и рассмотрения более глубокого использования вторичного сырья в условиях АО «Шубарколь Комир».

Методика. Исходя из существующей технологии коксования, на базе предприятия были испытаны два варианта температурного воздействия на уголь. Первый вариант - нагрев угля до $900{ }^{\circ} \mathrm{C}$, который проводится путём медленного термолиза угля в потоке восходящих газов. Второй вариант - скоростное нагревание угля до $900{ }^{\circ} \mathrm{C} \mathrm{c}$ дальнейшей погрузкой выделяющихся продуктов в камеру для дополнительного пиролиза при $800{ }^{\circ} \mathrm{C}$, который проводится с развитием реакций с участием кислородсодержащих газов из печи и извне.

Результаты. На производственной площадке и в лабораторных условиях определены состав и качественные характеристики продуктов термической обработки длиннопламенного угля при различных температурных воздействиях. Отмечены различия в составе продуктов разложения и определен количественный их выход.

Научная новизна. Получены аналитические данные по продуктам коксования и установлены зависимости их количественных и физических параметров от разных вариантов применения термолиза на углях Шубаркольского месторождения.

Практическая значимость. Результаты работы позволяют совершенствовать технологию коксового производства путем введения дополнительной стадии пиролиза, которая приведет к улучшению потребительских свойств кокса, а также создают условия для разработки методик использования вторичных продуктов производства.

Ключевые слова: уголь, Шубарколь, летучие вещества, пиролиз, коксование, термолиз, термическое разложение

Recommended for publication by T.K. Isabek, Doctor of Technical Sciences. The manuscript was submitted 28.02.20. 